\title{
Infection of the epididymis by Ureaplasma urealyticum
}

\author{
N JALIL, A DOBLE, C GILCHRIST, D TAYLOR-ROBINSON \\ From the Jefferiss Research Wing of the Praed Street Clinic, St. Mary's Hospital, Paddington, London; and the \\ Division of Sexually Transmitted Diseases, Clinical Research Centre, Watford Road, Harrow, Middlesex
}

SUMMARY Ureaplasma urealyticum organisms (ureaplasmas) were isolated from the urethra and epididymal aspirate of a man aged 24 who had acute right sided epididymitis. No other microorganisms were detected, and he had no chlamydial antibody response. A fourfold antibody response to the epididymal ureaplasma isolate was detected by two methods, however, and the patient responded clinically to doxycycline, to which the ureaplasmal isolates were susceptible in vitro. These findings suggest that $U$ urealyticum had a causative role.

Ureaplasmas, found in the genitourinary and respiratory tracts of some mammalian and avian species, are unique among the order Mycoplasmatales in their ability to metabolise urea. The genus Ureaplasma contains three species, ureaplasmas found in man being classified in the genus and species, $U$ urealyticum. The organisms are found in the genitourinary tract of some healthy men, ${ }^{1}$ but there has been cumulative evidence, which has become increasingly difficult to refute, that they cause a proportion of cases of non-gonococcal urethritis, ' and they certainly do so in patients with impaired immunity. ${ }^{2}$ The possibility that $U$ urealyticum might be implicated in other conditions of the genitourinary tracts of men has often been discussed. Indeed, Harnisch and colleagues suggested it more than a decade ago as a possible cause of acute epididymitis, ${ }^{3}$ but the same group of workers failed to find support for the hypothesis in their subsequent studies based on epididymal aspiration. ${ }^{4}$ Their findings indicated that epididymitis is caused mainly by Chlamydia trachomatis in patients younger than 35 and by urinary tract pathogens in older patients. Other studies have not provided evidence to refute these findings, ${ }^{56}$ although they were limited to the possible role of $C$ trachomatis and have not entailed epididymal aspiration. Recently, Doble and colleagues have undertaken the first study of acute epididymitis in the United Kingdom, in which epididymal aspirates have been examined microbiologically. ${ }^{7}$ We report in detail the findings in one case.

Address for reprints: Dr D Taylor-Robinson, Division of Sexually Transmitted Diseases, Clinical Research Centre, Watford Road, Harrow, Middlesex HA1 3UJ

Accepted for publication 13 July 1988

\section{Case report}

A man aged 24 presented to the accident and emergency department of St Mary's Hospital with a two day history of testicular pain and swelling. He had no discharge or dysuria or any history of sexually transmitted disease. On examination, he had scrotal swelling with a palpably enlarged right testis and epididymis, the latter being extremely tender. Rectal examination showed a normal prostate. The remainder of the examination showed no abnormality. Urethral swabs and a midstream urine sample were obtained and examined microbiologically as outlined below. In view of the possibility of testicular torsion, the patient underwent exploration of the testis under general anaesthesia. The operative findings were of an enlarged viable testis with no evidence of torsion. The epididymis was distended and severely hyperaemic, and $1.0 \mathrm{ml}$ of turbid fluid was aspirated for microbiological assessment. The patient was then subjected to transrectal prostatic ultrasound examination, after which he was treated with doxycycline $100 \mathrm{mg}$ twice a day for one week and $100 \mathrm{mg}$ daily for five weeks. He made an uneventful recovery.

\section{MICROBIOLOGICAL INVESTIGATIONS AND FINDINGS}

$U$ urealyticum organisms were isolated from an urethral swab and the epididymal aspirate in a conventional manner, the specimens being diluted serially in liquid medium. ${ }^{8}$ More organisms were found in the epididymal aspirate $\left(\geqslant 10^{4}\right.$ colour changing units (ccu/ $\mathrm{ml})$ than in the urethral swab $\left(10^{3} \mathrm{ccu} / \mathrm{ml}\right)(\mathrm{table}) . C$ trachomatis was sought in urethral and aspirate specimens by direct immunofluorescence using a monoclonal antibody (MictoTrak, Syva, UK), ${ }^{9}$ but was not detected. Nor was there evidence in such 
Table Results of microbiological investigations of a man with epididymitis

\begin{tabular}{|c|c|c|c|c|}
\hline \multirow[b]{2}{*}{ Stage of disease } & \multirow[b]{2}{*}{$\begin{array}{l}\text { Sites yielding } \\
\text { ureaplasmas (ccu/ml) }\end{array}$} & \multirow{2}{*}{$\begin{array}{l}\text { Susceptibility of } \\
\text { ureaplasmas to } \\
\text { doxycycline (MIC) }\end{array}$} & \multicolumn{2}{|c|}{ Titre of antibody to Ureaplasma urealyticum by: } \\
\hline & & & Microimmunofluorescence & $\begin{array}{l}\text { Metabolism } \\
\text { inhibition }\end{array}$ \\
\hline Acute & $\begin{array}{l}\text { Urethra } \quad\left(10^{3}\right) \\
\text { Epididymis }\left(\geqslant 10^{4}\right)\end{array}$ & $\begin{array}{l}0.125 \mu \mathrm{g} / \mathrm{ml} \\
0.125 \mu \mathrm{g} / \mathrm{ml}\end{array}$ & $1 / 16$ & $1 / 16$ \\
\hline Convalescent & & & $1 / 64$ & $1 / 64$ \\
\hline
\end{tabular}

$\mathrm{ccu}=$ colour changing units MIC $=$ minimum inhibitory concentration .

specimens of Neisseria gonorrhoeae, Mycoplasma hominis, or anaerobes, and urinary tract pathogens were not found in the urine.

Serological studies supported the finding of $U$ urealyticum in the epididymis. The epididymal isolate was grown and used as antigen in an immunofluorescence test to detect IgG and IgM antibody. ${ }^{10} \mathrm{~A}$ fourfold rise in the titre of IgG antibody to $U$ urealyticum was shown-it was $1 / 16$ in serum obtained in the acute phase and 1/64 in serum obtained one month later in the convalescent phase. A comparable serological response was seen when the metabolism inhibition test was used, " antibody titres of $1 / 16$ and $1 /$ 64 being found in the corresponding sera (table). Antibody to $C$ trachomatis could not be detected in these sera by microimmunofluorescence. ${ }^{12}$

The susceptibility of the ureaplasmal isolates to doxycycline was assessed by a microdilution broth method. ${ }^{13}$ Both isolates were sensitive, the minimum inhibitory concentration being $0.125 \mu \mathrm{g} / \mathrm{ml}$ (table).

\section{Discussion}

We detected $U$ urealyticum organisms in the epididymal aspirate of only one of 24 patients with acute epididymitis, six of whom yielded them from the urethra.' The occurrence of the organisms in both anatomical sites, however, and an even larger number in the aspirate than in the urethra, indicated that there was canalicular spread. This finding, together with an antibody response detected by two methods, and therefore not spurious, shows unquestionably that in this case there was deep seated ureaplasmal infection, and not just colonisation. The failure to detect any other micro-organism, including $C$ trachomatis, and the rapid clinical response to prolonged treatment with doxycycline, to which the ureaplasmas were sensitive in vitro, also suggested that $U$ urealyticum had a causative role. The prostatic ultrasound scan showed bilateral mid range echoes. Though these may indicate fibrotic changes, they may also indicate an inflammatory response, ${ }^{14}$ possibly due to prostatic infection. We felt that this was sufficient justification for treating the patient for longer than usual. Undertaking aspiration studies routinely on patients with acute epididymitis to search for ureaplasmas is prob- ably not warranted, but it would be worthwhile undertaking ureaplasmal serology on paired sera from any patient with epididymitis who has ureaplasmas in the urethra. A serological response would suggest a more deep seated infection and the possible implication of these organisms.

\section{References}

1 Taylor-Robinson D. Mycoplasmal and mixed infections of the human male urogenital tract and their possible complications. In: Razin S, Barile MF, eds. The mycoplasmas. Vol 4. London: Academic Press, 1985:27-63.

2 Taylor-Robinson D, Furr PM, Webster ADB. Ureaplasma urealyticum causing persistent urethritis in a patient with hypogammaglobulinaemia. Genitourin Med 1985;61:404-8.

3 Harnisch JP, Berger RE, Alexander ER, Monda G, Holmes KK. Aetiologyrof acute epididymitis. Lancet 1977;i:819-21.

4 Berger RE, Alexander ER, Harnisch JP, Paulsen CA, Monda GD, Ansell J, Holmes KK. Etiology, manifestations and therapy of acute epididymitis: prospective study of 50 cases. J Urol 1979; 121:750-4.

5 Hawkins DA, Taylor-Robinson D, Thomas BJ, Harris JRW. Microbiological survey of acute epididymitis. Genitourin Med 1986;62:342-4.

6 Mulcahy FM, Bignell CJ, Rajakumar R, et al. Prevalence of chlamydial infection in acute epididymo-orchitis. Genitourin Med 1987;63:16-8.

7 Doble A, Taylor-Robinson D, Thomas BJ, Jalil N, Harris JRW, Witherow RO'N. Acute epididymitis: a microbiological and ultrasonographic study. Br J Urol (in press).

8 Taylor-Robinson D, Furr PM. Recovery and identification of human genital tract mycoplasmas. Isr J Med Sci 1981;17: 648-53.

9 Thomas BJ, Evans RT, Hawkins DA, Taylor-Robinson D. Sensitivity of detecting Chlamydia trachomatis elementary bodies in smears by use of a fluorescein-labelled monoclonal antibody: comparison with conventional chlamydial isolation. $J$ Clin Pathol 1984;37:812-6.

10 Furr PM, Taylor-Robinson D. Micro-immunofluorescence technique for detection of antibody to Mycoplasma genitalium. $J$ Clin Pathol 1984;37:1072-4.

11 Purcell RH, Taylor-Robinson D, Wong D, Chanock RM. Color test for the measurement of antibody to T-strain mycoplasmas. J Bacteriol 1966;92:6-12.

12 Thomas BJ, Reeve P, Oriel JD. Simplified serological test for antibodies to Chlamydia trachomatis. J Clin Microbiol 1976;4: 6-10.

13 Evans RT, Taylor-Robinson D. The incidence of tetracyclineresistant strains of Ureaplasma urealyticum. $J$ Antimicrob Chemother 1978;4:57-63.

14 Doble A, Thomas BJ, Walker MM, Harris JRW, Witherow RO'N, Taylor-Robinson D. The role of Chlamydia trachomatis in chronic abacterial prostatitis: a study utilising ultrasound guided biopsy. J Urol (in press). 